\title{
Identification of Hanwoo (Native Korean Cattle Breed) Beef by Real-time PCR Using the MC1R Gene in 5 Provinces of South Korea
}

\author{
Jung-Min Park, Jin-Ho Shin, Dan-Won Lee, Jae-Chul Song ${ }^{1}$, Hyung-Joo Suh², \\ Un-Jae Chang ${ }^{3}$, and Jin-Man Kim* \\ Department of Food Science and Biotechnology of Animal Resources, Konkuk University, Seoul 143-701, Korea \\ ${ }^{1}$ Department of Food and Nutrition, Ulsan University, Ulsan 640-749, Korea \\ ${ }^{2}$ Department of Food and Nutrition, Korea University, Seoul 136-703, Korea \\ ${ }^{3}$ Department of Food and Nutrition, Dongduk Women's University, Seoul 136-714, Korea
}

\begin{abstract}
This paper describes the differentiation between native Korean cattle (Hanwoo) and Holsteins or imported cattle using the real-time polymerase chain reaction (PCR) by targeting the sequence of the melanocortin 1 receptor (MC1R) gene. A rapid and accurate method was developed to identify Hanwoo by genotyping the DNA extracted from 295 commercial beef samples (obtained from 5 provinces in South Korea) labeled as Hanwoo beef. The results of real-time PCR assays for the proportions of Hanwoo were 84, 85.7, 95, 91.4, and 90\% in the areas of Seoul, Joongbu, Youngnam, Honam, and Chungcheong, respectively. Thus, the beef samples from 295 butcher shops, which asserted to only sell Hanwoo, showed that 259 of 295 samples were of the Hanwoo beef gene type (T-type) and 36 of 295 samples were Holsteins of imported dairy cattle gene types (C-type or $\mathrm{C} / \mathrm{T}$ type). In conclusion, the proportion of Hanwoo beef was $87.8 \%$ and the proportion of Holstein or imported dairy cattle meat was $12.2 \%$ (C-type: $9.8 \%$, C/T-type: $2.4 \%$ ). Generally, most consumers can not differentiate imported meat from Hanwoo beef. Therefore, Hanwoo beef and imported dairy cattle meat that is sold in butcher shops should have mandatory identification by using MC1R genotyping based on real-time PCR.
\end{abstract}

Key words: Hanwoo (Korean native cattle), real time PCR, MC1R

\section{Introduction}

Korean consumers prefer beef from Korean native cattle (Hanwoo) to imported beef because they believe that juiciness and flavor of Hanwoo beef are better than those of imported beef (Kim et al., 1993). Therefore, Hanwoo beef has been regarded as the most expensive and high quality beef in South Korea. However, misbranded meat is often a target for fraudulent labeling because producers may replace more expensive products by others of inferior quality (Pfeiffer et al., 2004).

In order to protect consumers and ensure meat traceability, many molecular techniques have been reported for food authentication in an effort to prevent fraud (Koh et al., 1998).

Although, in general, coat color and visual discrimina-

\footnotetext{
*Corresponding author : Jin-Man Kim, Department of Food Science and Biotechnology of Animal Resources, Konkuk University, Seoul 143-701, Korea. Tel: 82-2-450-3688, Fax: 82-2-455-1044, E-mail: jinmkim@konkuk.ac.kr
}

tion are used frequently as district methods of breed identification, discrimination of slaughtered cattle is impossible. Recently, it has become possible to distinguish between breeds of cattle owing to developments in the field of biotechnology at the DNA level. The use of PCR in molecular diagnostics has increased to the point where it is now accepted as the gold standard for detecting nucleic acids from a number of origins, and it has became an essential tool in the research laboratory (Fairbrother et al., 1998; Lockely and Bardsley, 2002; Matsunuga et al., 1999). Real-time PCR has engendered wider acceptance of the PCR method owing to its improved rapidity, sensitivity, reproducibility, and the reduced risk of carry-over contamination (Brodmann and Moor, 2003; Dooley et al., 2004; Hird et al., 2004). The application of real-time PCR has provided significant methodological benefits and improved patient outcomes. We used forward and reverse primers and 2 TaqMan MGB probes to distinguish the MC1R gene. The polymorphic forms of the melanocortin-1 receptor (MC1R) are useful markers to distinguish between different breeds of domestic animals 
(Crepaldi et al., 2005). Mutations in the color locus in mammals can affect pigmentation of the hair, skin, and/or eyes. Thus far, MC1R has been studied in several animals especially for determining the purity of products labeled as derived from specific breeds (Russo et al., 2007; Fajardo et al., 2008). MC1R plays a central role in the regulation of eumelanin (black/brown) and phaeomelanin (red/yellow) synthesis within the mammalian melanocyte and is encoded by the classical Extension (E) coat color locus (Klungland et al., 1995; Searle, 1968). Thus, a single base substitution ( $\mathrm{T} \rightarrow \mathrm{C}$ transition) at the codon for amino acid position 99 of the MC1R gene was identified between Hanwoo and Holstein or imported breeds (Kim et al., 2005).

Owing to significant progress in molecular technology, real-time PCR using the MC1R gene has been used for population discrimination in livestock animals (Cameron et al., 2003; Fajardo et al., 2006).

The aim of this study was to detect the presence of Hanwoo, Holstein, or imported beef in Korea, where data are available rarely, by using the real-time PCR method for MC1R polymorphism. A total of 295 beef samples that were labeled as Hanwoo beef were collected from 5 provinces in Korea, including Seoul, Joongbu, Youngnam, Honam, and Chungcheong.

\section{Materials and Methods}

\section{Meat samples}

Meat samples were obtained from the 5 provinces of Korea. Samples of fresh raw meats with the label "Hanwoo" were obtained from local suppliers in Korea, including Seoul (25 regions, 100 samples), Joongbu (4 regions, 70 samples), Youngnam (40 samples), Honam (35 samples), and Chungcheong (50 samples). All samples were stored at $4^{\circ} \mathrm{C}$ until use.

\section{DNA extraction from raw meat}

DNA was extracted from raw meat using a modified PowerPrep $^{\mathrm{TM}}$ DNA Extraction kit (Kogene Biotech, Seoul, Korea). Each $10 \mathrm{mg}$ sample was diluted with 400 $\mu \mathrm{L}$ of lysis buffer $\mathrm{A}$ and $40 \mu \mathrm{L}$ of lysis buffer B in a microtube and mixed for $10 \mathrm{sec} ; 5 \mu \mathrm{L}$ of proteinase was added before incubation at $65^{\circ} \mathrm{C}$ for $30 \mathrm{~min}$; then, $400 \mu \mathrm{L}$ of chloroform was added, and the samples were centrifuged for $10 \mathrm{~min}$ at $12,000 \mathrm{rpm}$. Supernatant of volume $300 \mu \mathrm{L}$ was used to extract the DNA according to the manufacturer's instructions. DNA was stored for a short term at $4^{\circ} \mathrm{C}$ or for long term at $-20^{\circ} \mathrm{C}$.
Real-time PCR primers and TaqMan MGB probes

The following universal oligonucleotide primers were used: MC1R-FW (5'-GCTGGAGACGGCAGTCAT-3'; positions 559 to 576) and MC1R-RW (5'-TCCAGCTGCTGCACCAC-3'; positions 617 to 633); these primers were expected to yield a specific DNA fragment of $75 \mathrm{bp}$ in all the samples. Further, the following probes were used: 6-carboxyfluorescein (FAM)-labeled TaqMan MGB probe (5'-FAM-CCAGGACACCGCCT-MGB-3') that recognizes the missed guanine allele and VIC-labeled TaqMan MGB probe (5'-VIC-CCAGGACACGGCCT-MGB$\left.3^{\prime}\right)$ that recognizes existent guanine allele (Livak, 1999). The primer and probe sets were used using real-time PCR Kit (Kogene Biotech, Seoul, Korea) by mixing.

\section{Amplification of MC1R by real-time PCR}

For each real-time PCR, a $10 \mu \mathrm{L}$ of reaction mixture was used containing $50 \mathrm{ng}$ of template DNA, $2 \mu \mathrm{L}$ of primer mixture, $1 \mu \mathrm{L}$ of probe mixture, and $5 \mu \mathrm{L}$ of $2 \times$ master mix. Reactions were assembled in Axygen thin-walled 96 well plates with optical caps and run on a real-time PCR 7700 system (GeneAmp PCR System 9600 Thermal cycler, Perkin Elmer, CA, USA) with the following thermal cycling protocol: activation of uracil DNA glycosylase (UDG) for $3 \mathrm{~min}$ at $50^{\circ} \mathrm{C}$; initial denaturation of DNA for $2 \mathrm{~min}$ at $94^{\circ} \mathrm{C}$; 40 cycles consisting of denaturation of DNA for $30 \mathrm{sec}$ at $94^{\circ} \mathrm{C}$, annealing for $30 \mathrm{sec}$ at $60^{\circ} \mathrm{C}$, and extension for $30 \mathrm{sec}$ at $72^{\circ} \mathrm{C}$; and final incubation for $5 \mathrm{~min}$ at $72^{\circ} \mathrm{C}$.

\section{Analysis of data}

The graphs were compared to determine whether the samples contained Hanwoo, Holstein, or mixed Hanwoo and Holstein beef.

\section{Results and Discussion}

Because consumers want to be protected from falsely labeled meat products, food labeling regulations require the identification of meat in the meat products so that they are accurately labeled (Krkoska et al., 2003; Pascal and Mahe, 2001). In results for the analysis of the 99TC mutation in the MC1R gene, VIC-labeled probe was used to detect the Holstein and imported beef (Allele T), and a FAM-labeled probe was used to detect the Hanwoo (Korean Native Cattle) beef (Allele C) (Kim et al., 2005; Klungland et al., 1995; Park et al., 2005; Rouzaud et al., 2000).

The Holstein and Angus cattle have the sequence GGT 
(Gly), but the Hanwoo cattle has the sequence GTG (Val) at the corresponding position, which results in an amino acid change (Gly to Val). Additionally, in Angus cattle, we found a single base substitution (T to C) at the $99 \mathrm{bp}$ position, resulting in an amino acid change (Leu to Pro). Thus, as seen in Fig. 1, we distinguished between Hanwoo, Holstein, and Angus cattle using real-time PCR, and we proved that real-time PCR was better than existing methods for identification of the source of the beef.

As seen in Table 1, most samples (from 11 of 25 wards in Seoul) (100\%), including samples from Gangnam, Gwanak, Geumcheon, Dobong, Dongdaemoon, Dongjak, Seocho, Sungdong, Songpa, Eunpyung, and Joonglang, were found to originate from Hanwoo cattle as identified by the coat color of cattle containing the T type gene. On the other hand, the samples from 12 of 25 wards ( $75 \%$ shop), including Gangdong, Gangbuk, Gangseo, Gwangjin, Guro, Nowon, Mapo, Yangcheon, Youngdeungpo, Yongsan, Jonglo, and Joong, were found to contain the T type gene (Hanwoo cattle), and the remaining 25\% shop of the samples were found to contain the $\mathrm{C}$ type gene or $\mathrm{C} / \mathrm{T}$ type. Although all samples were labeled as Hanwoo beef, samples from 2 of 25 wards, Sungbuk and Seodaemun, were found to contain the genes of Holstein or imported cattle (C/T type or C type) with 50\%. From Seoul, the Korean capital, 100 samples were obtained from butcher

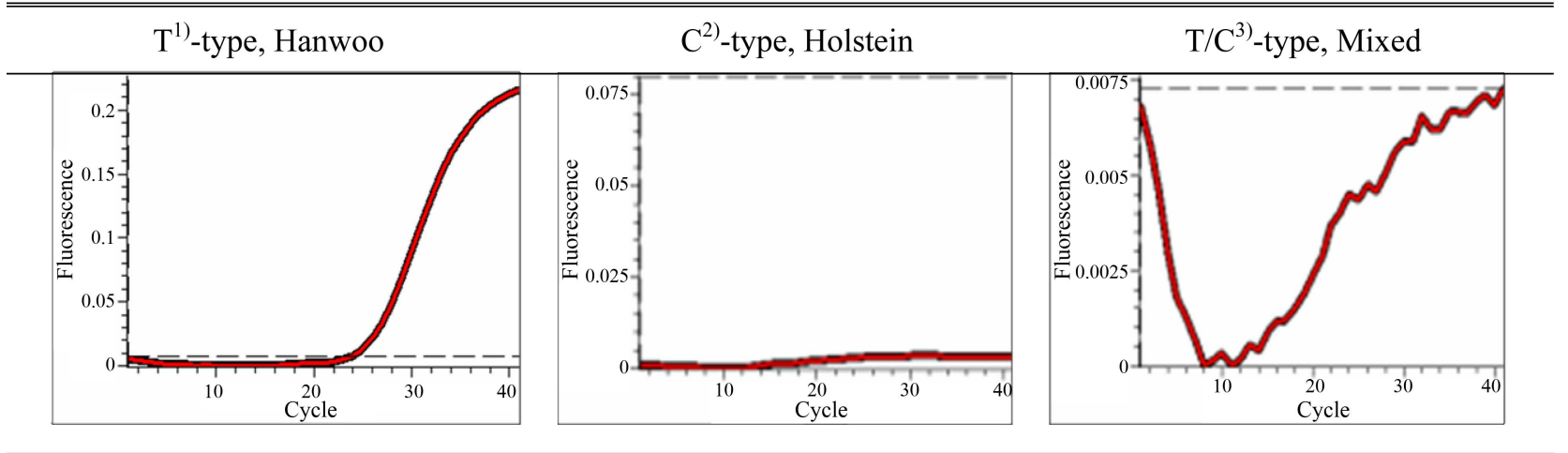

Fig. 1. Amplication plots for two alleles of the MC1R gene. Templates were a known homozygote for the $\mathrm{T}$ allele and a known homozygote for the $\mathrm{C}$ allele and heterozygote for the mixed $\mathrm{T}$ and $\mathrm{C}$ alleles. In this case, fluorescene was monitired during the thermal cycling of real-time PCR on the GeneAmp PCR System 9600. ${ }^{1)} \mathrm{T}$ :MC1R gene of Hanwoo (Korean Native Cattle) Beef. ${ }^{2)} \mathrm{C}: \mathrm{MC} 1 \mathrm{R}$ gene of Holstein cattle beef. ${ }^{3)} \mathrm{C} / \mathrm{T}$ :MC1R gene possessed of Hanwoo and Holstein cattle beef.

Table 1. The results of meat species using real-time PCR for beef samples with Hanwoo (Korean native cattle) labeling in Seoul including 25 wards ( 4 butcher shops/ward)

\begin{tabular}{|c|c|c|c|c|c|c|c|c|c|c|c|}
\hline \multirow{2}{*}{ Ward } & \multicolumn{4}{|c|}{ Type $^{1 /} /$ Breed $^{2)}$} & \multirow{2}{*}{$\%^{3)}$} & \multirow{2}{*}{ Ward } & \multicolumn{4}{|c|}{ Type/Breed } & \multirow{2}{*}{$\%$} \\
\hline & 1 & 2 & 3 & 4 & & & 1 & 2 & 3 & 4 & \\
\hline Gangnam & $\mathrm{T}^{4)} / \mathrm{Han}$ & T/Han & T/Han & T/Han & 100 & Seodaemoon & $\mathrm{C} \cdot \mathrm{T} / \mathrm{Mix}$ & T/Han & T/Han & $\mathrm{C} \cdot \mathrm{T} / \mathrm{Mix}$ & 50 \\
\hline Gangdong & $\mathrm{T} / \mathrm{Han}$ & $\mathrm{C}^{5)} / \mathrm{Hol}$ & $\mathrm{T} / \mathrm{Han}$ & T/Han & 75 & Seocho & T/Han & $\mathrm{T} / \mathrm{Han}$ & $\mathrm{T} / \mathrm{Han}$ & T/Han & 100 \\
\hline Gangbuk & T/Han & T/Han & T/Han & $\mathrm{C} / \mathrm{Hol}$ & 75 & Sungdong & T/Han & $\mathrm{T} / \mathrm{Han}$ & T/Han & T/Han & 100 \\
\hline Gangseo & T/Han & $C \cdot T^{6 / /} \operatorname{Mix}$ & $\mathrm{T} / \mathrm{Han}$ & T/Han & 75 & Sungbuk & $\mathrm{C} / \mathrm{Hol}$ & $\mathrm{T} / \mathrm{Han}$ & $\mathrm{T} / \mathrm{Han}$ & $\mathrm{C} / \mathrm{Hol}$ & 50 \\
\hline Gwanak & T/Han & T/Han & $\mathrm{T} / \mathrm{Han}$ & T/Han & 100 & Songpa & T/Han & $\mathrm{T} / \mathrm{Han}$ & $\mathrm{T} / \mathrm{Han}$ & $\mathrm{T} / \mathrm{Han}$ & 100 \\
\hline Gwangjin & T/Han & T/Han & $\mathrm{C} / \mathrm{Hol}$ & T/Han & 75 & Yangcheon & T/Han & $\mathrm{T} / \mathrm{Han}$ & $\mathrm{T} / \mathrm{Han}$ & $\mathrm{C} \cdot \mathrm{T} / \mathrm{Mix}$ & 75 \\
\hline Guro & T/Han & $\mathrm{T} / \mathrm{Han}$ & $\mathrm{T} / \mathrm{Han}$ & $\mathrm{C} / \mathrm{Hol}$ & 75 & Yeongdeungpo & $\mathrm{T} / \mathrm{Han}$ & $\mathrm{C} / \mathrm{Hol}$ & T/Han & T/Han & 75 \\
\hline Geumcheon & T/Han & T/Han & $\mathrm{T} / \mathrm{Han}$ & T/Han & 100 & Yongsan & $\mathrm{C} / \mathrm{Hol}$ & $\mathrm{T} / \mathrm{Han}$ & $\mathrm{T} / \mathrm{Han}$ & T/Han & 75 \\
\hline Nowon & T/Han & $\mathrm{C} / \mathrm{Hol}$ & $\mathrm{T} / \mathrm{Han}$ & T/Han & 75 & Eunpyung & T/Han & $\mathrm{T} / \mathrm{Han}$ & $\mathrm{T} / \mathrm{Han}$ & T/Han & 100 \\
\hline Dobong & $\mathrm{T} / \mathrm{Han}$ & $\mathrm{T} / \mathrm{Han}$ & $\mathrm{T} / \mathrm{Han}$ & T/Han & 100 & Jonglo & $\mathrm{C} / \mathrm{Hol}$ & $\mathrm{T} / \mathrm{Han}$ & $\mathrm{T} / \mathrm{Han}$ & T/Han & 75 \\
\hline Dongdaemoon & T/Han & T/Han & $\mathrm{T} / \mathrm{Han}$ & T/Han & 100 & Joong & $\mathrm{C} / \mathrm{Hol}$ & $\mathrm{T} / \mathrm{Han}$ & $\mathrm{T} / \mathrm{Han}$ & T/Han & 75 \\
\hline Dongjak & $\mathrm{T} / \mathrm{Han}$ & T/Han & $\mathrm{T} / \mathrm{Han}$ & T/Han & 100 & Joonglang & $\mathrm{T} / \mathrm{Han}$ & $\mathrm{T} / \mathrm{Han}$ & $\mathrm{T} / \mathrm{Han}$ & T/Han & 100 \\
\hline Mapo & T/Han & T/Han & $\mathrm{T} / \mathrm{Han}$ & $\mathrm{C} \cdot \mathrm{T} / \mathrm{Mix}$ & 75 & & & & & & \\
\hline
\end{tabular}

\footnotetext{
1) Type: gene of beef.

${ }^{2)}$ Breed: species of beef.

3) Represent Hanwoo (Korean native cattle) samples percent.

4) T:MC1R gene of Hanwoo (Korean native cattle) beef.

${ }^{5)} \mathrm{C}: \mathrm{MC} 1 \mathrm{R}$ gene of Holstein cattle beef.

${ }^{6} \mathrm{C} / \mathrm{T}: \mathrm{MC} 1 \mathrm{R}$ gene possessed of Hanwoo, Holstein cattle beef.
} 
Table 2. The results of Real-time PCR for beef samples with Hanwoo (Korean native cattle) labeling in Seoul, Joongbu, Youngnam, Honam, and Chungcheong

\begin{tabular}{llcccc}
\hline \hline \multirow{2}{*}{ Province } & \multirow{2}{*}{$\begin{array}{c}\text { Breed } \\
\text { ward }\end{array}$} & T/Hanwoo & \multicolumn{3}{c}{ Genotype } \\
\cline { 3 - 5 } & C/Holstein & C ${ }^{2)}$ & T/Mix ${ }^{3)}$ & $100(100)$ \\
Seoul & 25 wards & $84^{4)}(84)^{5)}$ & $11(11)$ & $5(5)$ & $100(15)$ \\
Joongbu & Gangnung & $100(15)$ & & $6.7(1)$ & $100(15)$ \\
& Ansan & $86.6(13)$ & $6.7(1)$ & $100(20)$ \\
& Koyang & $80(16)$ & $20(4)$ & $100(20)$ \\
Chungcheong & Suwon & $80(16)$ & $20(4)$ & $100(50)$ \\
Youngnam & & $90(45)$ & $10(5)$ & $100(40)$ \\
Honam & & $95(38)$ & $5(2)$ & $2.9(1)$ & $100(35)$ \\
\hline Total & & $91.4(32)$ & $5.7(2)$ & $2.4(7)$ & $100(295)$ \\
\hline
\end{tabular}

1) T:MC1R gene of Hanwoo (Korean native cattle) Beef.

2) $\mathrm{C}: \mathrm{MC} 1 \mathrm{R}$ gene of Holstein cattle beef.

${ }^{3)} \mathrm{C} / \mathrm{T}: \mathrm{MC} 1 \mathrm{R}$ gene possessed of Hanwoo, Holstein cattle beef.

4) Number (\%) calculated from the total number .

${ }^{5)}$ Number of identified beef.

shops (25 wards, 100 shops) that claimed that they sell only Hanwoo beef; of these 100 samples, 84 samples contained the Hanwoo gene type (T type), while 16 samples contained the Holstein gene or imported cattle gene (C type or $\mathrm{C} / \mathrm{T}$ type).

The results for the samples obtained from five province including Seoul, Joongbu, Youngnam, Honam, and Chungcheong are given in Table 2. The Joongbu province consists of Gangnung, Ansan, Koyang, and Suwon. The results revealed that $100 \%$ of the samples from Gangnung (from all 15 cities) contained the Hanwoo cattle gene ( $\mathrm{T}$ type); $86.6 \%$ of the samples from Ansan (from 13 out of 15 cities) contained the Hanwoo cattle gene (T type), and the remaining samples contained the Holstein cattle gene (C type or $\mathrm{C} / \mathrm{T}$ type); further, $80 \%$ of the samples from Koyang and Suwon (from 16 out of 20 cities) contained the Hanwoo cattle gene (T type). In the Youngnam province, $95 \%$ of the samples (from 38 out of 40 cities) were found to contain the Hanwoo cattle gene (T type). In the Honam province, $91.4 \%$ of the samples (from 32 out of 35 cities) were found to contain the Hanwoo cattle gene (T type). In the Chungcheong province, $90 \%$ of the samples (from 45 out of 50 cities) were found to contain the Hanwoo cattle gene (T type). As seen in Fig. 2, our study was carried out to identify the Hanwoo beef by genotyping the DNA extracted from 295 commercial beef samples. Real-time PCR using MC1R revealed that $87.8 \%$ of the butchers sold authentic Hanwoo beef, while $12.2 \%$ of the butchers sold Holstein or imported beef fraudulently as Hanwoo beef. In conclusion, real-time PCR using the MC1R gene is a powerful technology, which is accurate,

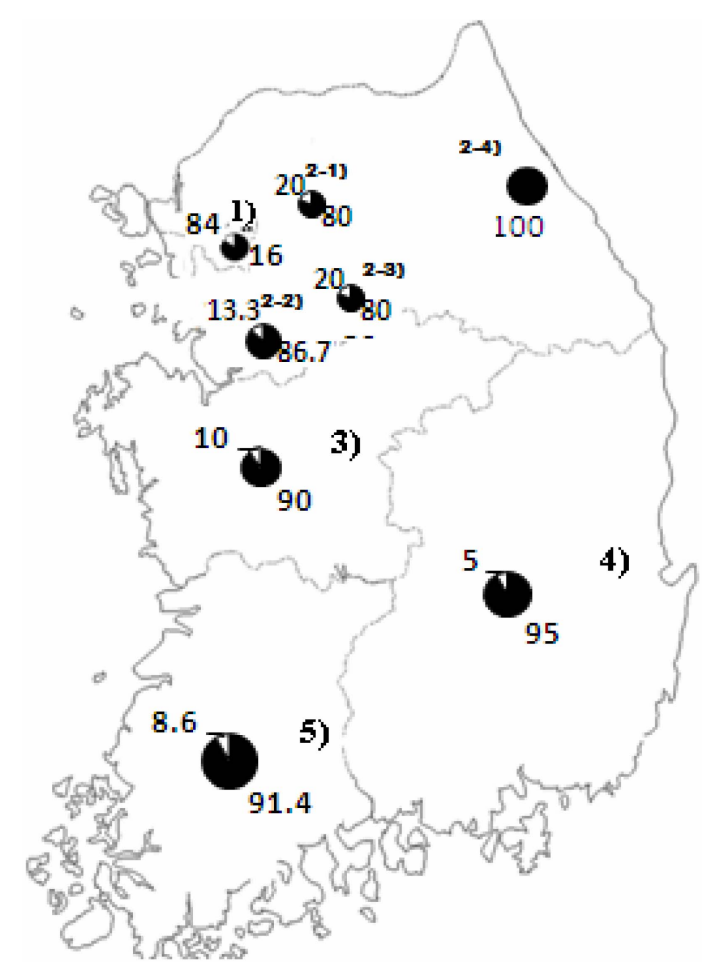

Fig. 2. Map showing the distribution of sampling sites of black in circle areas represent Hanwoo (Korean native cattle) samples percent while the white in circle areas represent fraud-beef samples percent that have been identified as Real-time PCR in Korea including 5 provinces. ${ }^{1)}$ Region of Seoul in Korea. ${ }^{2)}$ Region of Joongbu in Korea: ${ }^{2-1)}$ Koyang, ${ }^{2-2)}$ Ansan, ${ }^{2-3)}$ Suwon, ${ }^{2-}$ ${ }^{4)}$ Gangnung, ${ }^{3)}$ Region of Chungcheong in Korea. ${ }^{4}$ Region of Youngnam in Korea. ${ }^{5}$ Region of Honam in Korea.

simple, and relatively fast, with good sensitivity and specificity. The potential of the described procedure to detect 
the origin of the beef in a sample may make it a useful tool for inspection programs to enforce labeling regulations of game and other meat products. Thus, the method described in this study could be a useful initial molecular test for discrimination between Hanwoo and Holstein or imported beef, and it could contribute to the reduction of incorrect or falsified labeling of food. Additionally, in order to improve the ability to discriminate between the types of cattle, more effective methods using other combinations of genetic analysis are required.

\section{Acknowledgements}

This study was supported by Korean Federation of Housewives Clubs and the Brain Korean 21 (BK21) Project in Korea.

\section{References}

1. Brodomann, P. D. and Moor, D. (2003) Sensitive and semiquantitave TaqMan $^{\mathrm{TM}}$ real-time polymerase chain reaction systems for the detection of beef (Bos Taurus) and the detection of the family Mammalian in food and feed. Meat Sci. 65, 599-607.

2. Cameron, N. D., Van Eijk, M. J., Brugmans, B., and Peleman, J. (2003) Discrimination between selected lines of pigs using AFLP markers. J. Heredity 91, 494-501.

3. Crepaldi, P., Fornarelli, F., and Marilli, M. (2005) MC1R gene: comparison between different farm animal species. Ital. J. Anim. Sci. 4, 43-45.

4. Dooley, J. J., Paine, K. E., Garrett, S. D., and Brown, H. M. (2004) Detection of meat species using TaqMan real-time PCR assays. Meat Sci. 68, 431-438.

5. Fajardo, V., Gonzalez, I., Lopez-Calleja, I., Martin, I., Hernandez, P. E., Garcia, T., and Martin, R. (2006) PCR-RFLP authentication of meats from red deer (Cervus elaphus), fallow deer (Dama dama), roe deer (Capreolus capreolus), cattle (Bos taurus), sheep (Ovis aries), and goat (Capra hircus). J. Agric. Food Chem. 54, 1144-1150.

6. Fajardo, V., Gonzalez, I., Martin, I., Rojas, M., Hernandez, P. E., Garcia, T., and Martin, R. (2008) Differentiation of European wild boar (Sus scrofa scrofa) and domestic swine (Sus scrofa domestica) meats by PCR analysis targeting the mitochondrial D-loop and the nuclear melanocortin receptor 1 (MC1R) genes. Meat Sci. 78, 314-322.

7. Fairbrother, K. S., Hopwood, A. J., Lockely, A. K., and Bardsley, R. G. (1998) The actin multigene family and livestock speciation using the polymerase chain reaction. Anim. Biotechnol. 9, 89-100.

8. Hird, H., Goodier, R., Schneedem K., Boltz, C., Chisholm, J., Lloyd, J., and Popping, B. (2004) Truncation of oligonucleotide primers confers specificity on real time PCR assays for food authentication. Food Addit. Contam. 21, 1035-1040.
9. Kim, D. H., Kim, Y. K., Chung, Y. H., Yoo, Y. M., and Park, B. Y. (1993) A study on the consumer's attitude to beef: 1 . Consumer's purchasing pattern and preference. RDA. J. Agri. Sci. 35, 598-601.

10. Kim, J. M., Nam, Y. S., Choi, J. H., Lee, M. A., Jeong, J. Y., and Kim, C. J. (2005) Identification of Hanwoo (Korean Native Cattle) Beef in Restaurants using Real-time PCR. Korean J. food Sci. 25, 203-209.

11. Koh, M. C., Lim, C. H., Chua, S. B., Chew, S. T., and Phang, S. T. W. (1998) Random amplified polymerase DNA(RAPD) fingerprints for identification of red meat species. Meat Sci. 48, 275-285.

12. Klungland, H., Vage, D. I., Gomez-Raya, L., Adalsteinsson, S., and Lien, E. (1995) The role of melanocyte-stimulating hormone $(\mathrm{MSH})$ receptor in bovine coat colour determination. Mamm. Genome 6, 636-639.

13. Krkoska, L., Nebola, M., Steinhauserova, I., Obroska, I., and Ernst, M. (2003) Using the PCR-RFLP method. Fleischwirtschaft Int. 2, 39-42.

14. Livak, K. J. (1999) Allelic discrimination using fluorogenic probes and the 5' nuclease assay. Genet. Anal. 14, 143-149.

15. Lockely, A. K. and Bardsley, R. G. (2002) Intron variability in an actin gene can be used to discriminate between chicken and turkey DNA. Meat Sci. 61, 163-168.

16. Matsunuga, T., Chiki, K., Tanabe, R., Muroya, S., Shibata, K., Yamada, J., and Shinmura, Y. (1999) A quick and simple method for the identification of meat species and meat products by PCR assay. Meat Sci. 51, 143-148.

17. Pascal, G. and Mahe, S. (2001) Identity, traceability, acceptability and substantial equivalence food. Cell Mol. Biol. 47, 1329-1342.

18. Park, S., D, Kim, T. J., and Lee, J. I. (2005) Identification of Hanwoo and Holstein meat using MGB probe based realtime PCR associated with single nucleotide polymorphism (SNP) in Melanocortin 1 receptor (MC1R) gene. Korean $J$. Vet. Res. 45, 25-28.

19. Pfeiffer, I., Burger, J., and Brenig, B. (2004) Diagnostic polymorphisms in the mitochondrial cytochrome $b$ gene allow discrimination between cattle, sheep, goat, roe buck and red deer by PCR-RFLP. Genetics 5, 30-35.

20. Rouzaud, F., Martin, J., Gallet, P. F., Delourme, D., Goulemont-Leger, V., Amigues, Y., Menissier, F., Leveziel, H., Julien, R., and Oulmouden, A. (2000) A first genotyping assay of French cattle breeds based on a new allele of the extension gene encoding the melanocortin-1 receptor (Mc1r). Genet. Sel. Evol. 32, 511-520.

21. Russo, V., Fontanesi, L., Scotti, E., Tazzoli, M., Dall'Olio, A., and Davoli, R. (2007) Analysis of melanocortin 1 receptor (MC1R) gene polymorphisms in some cattle breeds: Their usefulness and application for breed traceability and authentication of Parmigiano Reggiano cheese. Ital. J. Anim. Sci. 6, 257-272.

22. Searle, A. G. (1968) Comparative genetics of coat colour in mammals. Logos Press, London.

(Received 2009.8.20/Revised 2009.10.19/Accepted 2009.11.10) 